V. Ievdokymov ${ }^{1}$, Dr. Sc. (Econ.), Prof., orcid.org/0000-0002-3577-081X, T. Ostapchuk ${ }^{1}$, Dr. Sc. (Econ.), Assoc. Prof., orcid.org/0000-0001-9623-0481, S. Lehenchuk ${ }^{2}$, Dr. Sc. (Econ.), Prof., orcid.org/0000-0002-3975-1210, D. Grytsyshen ${ }^{1}$, Dr. Sc. (Econ.), Prof., orcid.org/0000-0002-1559-2403, G. Marchuk ${ }^{1}$, orcid.org/0000-0003-2954-1057

\title{
ANALYSIS OF THE IMPACT OF INTANGIBLE ASSETS ON THE COMPANIES' MARKET VALUE
}

Purpose. To determine the impact of intangible assets on the market value of European companies (Germany, France and the United Kingdom) using intellectual data analysis.

Methodology. The correlation-regression analysis, including Python programming libraries (Pandas, Numpy, Matplotlib, and Seaborn), was used to find the link between market value and intangible assets available to enterprises, which allows conducting analysis and visualization of the results obtained through various methods. To analyze the impact of an industry type on the relationship between market value and intangible assets, their classification according to the NACE Code Index is used.

Findings. The correlation between intangible assets and the market value of companies in the analyzed European countries has been identified, but the strength of this connection is different (German companies (0.6-0.7), French companies (0.3-0.7), British companies $(0.5-0.7)$ ). The size of an enterprise affects the connection between intangible assets and the market value of enterprises. The authors conclude that the correlation between the intangible assets indicators by economic sectors and the market value of enterprises exists only for some economic sectors (C, J, K, M and N), classified according to the NACE Code Index.

Originality. The study presents the regression dependence of market value on intangible assets of European companies (Germany, France and the United Kingdom), which allows adjusting their investment policy depending on the industry to which the company belongs and on its size.

Practical value. Determining the possibility of the impact of the value of intangible assets on the market value of companies.

Keywords: intangible fixed assets, market value, market capitalization, intellectual data analysis, correlation, regression

Introduction. One of the most relevant areas of management development in the current environment is the introduction of a value-oriented management concept aimed at maximizing the value of companies. The development of this concept is due to the partial impossibility of an accounting system based on the use of statutory accounting standards (GAAP US, IAS/IFRS, GAAP UK, and others), to reflect in the financial statements the real market value of a company formed in the capital markets. The prerequisite for the creation of this concept was the consequences of the Great Depression, which occurred in the United States in 1929, and finally formed in the 1980 s of the $20^{\text {th }}$ century, when the model of value calculation (EVA, MVA, SVA, CFROI, CVA) became widespread, and others), which allowed substantiating the reasons for the gap between its balance value and market value.

At the present stage of the development of the concept of value-based management, special attention is paid to the study of the influence of individual factors on the value creation process, one of the main among which are intangible assets and other non-capitalized resources of intellectual nature, which are considered the main factor for creating competitive advantages in the market and the generator of value of the enterprise in conditions of development of post-industrial economy. It is connected, mainly, with the companies' intellectual capital, a great amount of which provides the creation of value according to the accounting standards (GAAP US, IAS/IFRS, GAAP UK) and is not represented in the accounting system at all or is evaluated using a conservative approach. The existence of such a situation is called "an accounting value paradox of intangible assets" by R. Blaug and R. Lekhi (2009) and it dramatically complicates the efficient management of the company's value.

(C) Ievdokymov V., Ostapchuk T., Lehenchuk S., Grytsyshen D., Marchuk G., 2020
However, there are some issues in the context of the investigation, which have not been studied enough. They are as follows: 1) in what way the company's market value depends upon the level of intangible assets capitalization; 2) whether the level of the present dependence differs in different countries, branches of economic activities, and enterprises, which have different sizes and hold different volumes of intangible assets. Such scientists as J.-M. Sahut, S. Boulerne, F. Teulon (2011) and V. Nitsenko, V. Mukoviz, O. Sharapa [1] consider that low country differences persist despite the use of common accounting standards and legal and regulatory country characteristics as well as market forces could still have a significant impact on the value relevance of accounting data that confirms the possibility of national accounting specificity impact on the course of companies' value formation by the management of their intangible assets. Thus, substantiation and formalization of the interconnection between the intangible assets available to the enterprise and its market value, taking into account the national, branch and individual characteristics of the enterprises is an important scientific and applied task.

Literature review. Scientists engaged in the exploration of various fields including accounting and economic analysis, intellectual capital, and value-oriented management dedicated their publications to the determination of impact of intangible assets capitalization and research and development costs on the market value of companies. In addition, such studies concern both the impact of intangible assets on the market value and the impact of their components - separate types of intangible assets (software, trademarks), patents, research and development costs.

Hall B. H., Jaffe A. and Trajtenberg M. (2001) in "Market value and patent citations" proved the presence of dependence between the number of patents available in a company and its market value, in particular that the additional disclosure of information about patents increases the market value of the company by $3 \%$. 
Lev B. (2001) summarized the research studies existing at that time which were connected with the analysis of the impact of intangible assets on the market value of companies, and highlighted a number of arguments (companies with more intangible assets have higher cost of capital, undervaluation of intangible assets by investors) that substantiate the need in capitalization and presentation of intangible assets in the company's reporting as a result of their positive impact on the market value. D. J. Skinner (2008) disagreed with these arguments, he considers that there is some evidence that the market value of companies whose value is principally composed of intangibles differs from other companies; however, this result does not necessarily show anything about the desirability of particular accounting/ disclosure treatments. There is no evidence that the accounting or disclosure treatment of intangibles in and of itself results in systematically lower valuations for these companies.

However, the opinion of D. J. Skinner (2008) did not significantly influence the research in this area, which was continued by other scientists in the field of empirical verification of the impact of intangible assets and their components on the market value based on the use of regression models. In addition, B. Lev (2011) made an attempt to take into account and critically rethink D. J.Skinner's recommendations (2008), as a result of which the author continued to insist that the information on intangible assets was crucial for investors, since the latter played an important role in shaping the market value of companies.

Volkov D. and Garanina T. (2008) analyzed, by means of a two-factor regression model, the effect of the fundamental value of tangible and intangible factors on the market value of an enterprise, based on the example of 43 Russian companies listed in the Russian Trade System (RTS). One of the results obtained was the existence of significant differences in the impact of intangible assets on the process of formation of the market value in companies belonging to different sectors of the economy, which makes the relevance of this feature when conducting such analysis for enterprises in other countries.

Nitsenko V., Chukurna O., Mardani A., Streimikis J., Gerasymchuk N., Golubkova I., Levinska T. [2] considered the method of correlation-regression analysis also used for constructing a regression model of pricing. In particular, using the method of correlation-regression analysis, the authors proposed the formation of value through the use of methods for the formation of demand for innovative products.

Sahut J.-M., Boulerne S., Teulon F. (2011), analyzing the activities of 1855 European companies, whose shares are listed to exchanges, confirmed the connection between their market value and the balance value of their goodwill and other intangible assets. In particular, using the developed empirical models, the authors confirmed the existence of a positive impact of intangible assets and goodwill on stock prices, and found that intangible assets under international standards have informative value for explaining stock market returns.

Basso L.F.C., Saliba J.A. de Oliveira, H. Kimura and E. S. Braune [3] consider many scholars believe that knowledge has played an important role in the creation of companies' value and represents a source of sustainable competitive advantage for them. In particular, the authors researched the contribution of intangible assets in the creation of companies' value, using the methodology proposed by F. Gu and B. Lev and found out that the present methodology appears promising for the theoretical line of thought that seeks models to record the value of intangibles.

Jaara O. O. and Elkotayni Kh.A.R. [4] conducted the analysis of the impact of internally generated intangible assets on the formation of the market value of Jordanian pharmaceutical companies, using a two-factor regression model developed, the main components of which were research and development costs and patent costs disclosed in the notes to the financial statements. The analysis confirmed the existence of a significant impact of intangible assets on the market value of Jordanian pharmaceutical companies, but refuted the exis- tence of the direct connection between the number of patents disclosed and the market value of such businesses, as noted by B. H. Hall, A. Jaffe and M. Trajtenberg in their work (2001).

Also in recent years, the impact of intangible assets on market value in various European countries has been investigated by Nuryaman [5], F. Sardo and Z. Serrasqueiro [6], W. B. Castro and C. Benetti [7], J. Glova and S. Mrazkova [8], M. Ocak and D. Findik [9], T. Vasconcelos, D. Forte and L. F. C. Basso [10], W. Forte, G. Matonti and G. Nicolo [11], I. Mačerinskienė and S. Survilaite [12].

Unsolved aspects of the problem. Thus, the conducted analysis of empirical models used by scientists to analyze the impact of intangible assets and their components (software, research and development costs, published patents, goodwill) on the market value of the enterprise revealed the lack of a unified approach to their construction, which indicates the existence of a significant number of factors that may influence the level of this impact and, therefore, require further investigation.

Purpose. The aim of article is a determination of impact of intangible assets on the market value of companies using intellectual data analysis. The main tasks of the article are the following: to test the correlation between the intangible assets indicators and the market value of companies in selected European countries (UK, Germany and France); to test the correlation between the intangible assets indicators by companies' size and the market value of enterprises in individual countries (UK, Germany and France); to test the correlation between the intangible assets indicators by economic sectors and the market value of enterprises in individual countries (UK, Germany and France).

Methods. The article uses the correlation-regression analysis, which is understood as the quantitative method for determining the density and directions of the correlation between selective and variable indices. The Cheddock scale was used to estimate the connection strength, which assumes the existence of the following connection density: from 0.1 to 0.3 - weak interconnection strength; from 0.3 to $0.5-$ moderate connection strength; from 0.5 to 0.7 - sufficient strength of interconnections; from 0.7 to 0.9 - high strength of interconnections; from 0.9 to 1.0 - very high strength of interconnections.

In modern conditions, conducting the qualitative regression analysis involves the use of information technologies. Modern technologies of intellectual data analysis include a variety of methodological tools to build regression models that are formed on large data sets. Particularly noteworthy are the Python programming language, which contains the Pandas, Numpy, Matplotlib, and Seaborn libraries that allow correlation-regression analysis to be performed by various methods. This gives an opportunity to establish the impact of capitalization of intangible assets on the market capitalization index of the company, as well as to identify clearly the range of the indicators with which they are most correlated.

Results. The subject of the article study was selected involving European companies of individual countries (France, Germany, UK) of different industries that are a part of the "Top 500 E" (291 companies according to the period of the financial statements 2013-2017), and for which the necessary data are available (the balance value of all assets and intangible assets, market capitalization, number of employees, branch of industry for enterprises according to the NACE Code Index [13]). The financial information database "Amadeus - Bureau van Dijk" was used as the data source.

The regression dependence of market value on intangible assets can be represented as the following model

$$
M C=f(I F A, S, B),
$$

where $M C$ (market capitalization) is the market value, that is, the value of an enterprise that is determined on a stock exchange, may be affected by various factors; IFA is intangible fixed assets; $S$ is size of the enterprise; $B$ is a branch to which the enterprise belongs. 
The above model will be used by us to confirm or refute the following three working hypotheses:

H1. There is the correlation between the intangible assets indicators and the market value of companies in selected European countries (UK, Germany and France).

$$
M C=\beta_{0}+\beta_{1} I F A .
$$

H2. There is the correlation between the intangible assets indicators by companies' size and the market value of enterprises in individual countries (UK, Germany and France).

$$
M C=\beta_{0}+\beta_{1} I F A+\beta_{2} S .
$$

H3. There is the correlation between the intangible assets indicators by economic sectors and the market value of enterprises in individual countries (UK, Germany and France).

$$
M C=\beta_{0}+\beta_{1} I F A+\beta_{2} S+\beta_{3} B .
$$

The proposed research model for using Python programming libraries (Pandas - for intellectual analysis of numerical tables and time series; Numpy - enables the implementation of computational algorithms (in the form of functions and operators) that are optimized for working with multidimensional data sets; Matplotlib and Seaborn for data visualization) will confirm or refute the above hypotheses. Pandas dataframe.corr () is used to determine the pairwise correlation of all columns in a data frame.

First, we are testing the hypothesis 1. Based on the study of those indicators that were represented by European companies from different industries within the Top $500 \mathrm{EU}$, it was determined that, in the preliminary examination of the databases, it is advisable to use the Pearson correlation coefficient to deter- mine the density of connections. In addition, the method allows not taking into account indefinite indicators (n.a) and automatically excluding them from the calculations, and also allows excluding any columns with non-numeric indicators.

Conducting the first-hypothesis study will confirm or refute the existence of the correlations and interconnections between the intangible assets indicators and the market value of companies in certain countries (UK, Germany, and France).

The correlation of the indicators for the first hypothesis is represented by the following Python programming language code:

import pandas as pd

import seaborn as sns

import matplotlib.pyplot as plt

import numpy as np

pd.set_option('display.max columns', None)

data $=$ pd.read_csv("testTOP500Europe1.csv", delimiter $=$ ';’)

print(data.shape)

$\operatorname{print}($ data.corr $($ method $=$ 'pearson')

sns.heatmap $($ data $=$ data. $\operatorname{corr}()$, annot $=$ True, $\mathrm{fmt}=$ ". $1 \mathrm{f} "$, linewidths $=.6, \mathrm{cmap}=$ "YlGnBu")

plt.show().

Tables 1-3 summarize the indicators generated by this code for countries such as Germany, France and the United Kingdom.

Fig. 1 presents the correlation matrices for the reporting performance of companies in Germany, France, and the United Kingdom and summarized data about three countries that are a part of the Top 500 EU by the following indicators: Mar-

Table 1

Correlation of the indicators of market values and intangible assets of German enterprises for 2013-2017

\begin{tabular}{|l|c|c|c|c|c|}
\hline \multicolumn{1}{|c|}{ Germany } & $\begin{array}{c}\text { Market } \\
\text { capitalization } \\
(2017)\end{array}$ & $\begin{array}{c}\text { Market } \\
\text { capitalization } \\
(2016)\end{array}$ & $\begin{array}{c}\text { Market } \\
\text { capitalization } \\
(2015)\end{array}$ & $\begin{array}{c}\text { Market } \\
\text { capitalization } \\
(2014)\end{array}$ & $\begin{array}{c}\text { Market } \\
\text { capitalization } \\
(2013)\end{array}$ \\
\hline Intangible fixed assets (2017) & 0.647147 & 0.634419 & 0.659511 & 0.637277 & 0.617419 \\
\hline Intangible fixed assets (2016) & 0.639000 & 0.637734 & 0.662579 & 0.636792 & 0.617785 \\
\hline Intangible fixed assets (2015) & 0.671395 & 0.684713 & 0.705676 & 0.686663 & 0.671776 \\
\hline Intangible fixed assets (2014) & 0.590999 & 0.612190 & 0.614182 & 0.616794 & 0.603108 \\
\hline Intangible fixed assets (2013) & 0.597214 & 0.619985 & 0.620168 & 0.626331 & 0.616914 \\
\hline
\end{tabular}

Correlation of the indicators of market values and intangible assets of French enterprises for 2013-2017

\begin{tabular}{|l|c|c|c|c|c|}
\hline \multicolumn{1}{|c|}{ France } & $\begin{array}{c}\text { Market } \\
\text { capitalization } \\
(2017)\end{array}$ & $\begin{array}{c}\text { Market } \\
\text { capitalization } \\
(2016)\end{array}$ & $\begin{array}{c}\text { Market } \\
\text { capitalization } \\
(2015)\end{array}$ & $\begin{array}{c}\text { Market } \\
\text { capitalization } \\
(2014)\end{array}$ & $\begin{array}{c}\text { Market } \\
\text { capitalization } \\
(2013)\end{array}$ \\
\hline Intangible fixed assets (2017) & 0.454387 & 0.669052 & 0.362261 & 0.638711 & 0.649761 \\
\hline Intangible fixed assets (2016) & 0.417245 & 0.622773 & 0.286487 & 0.596294 & 0.602555 \\
\hline Intangible fixed assets (2015) & 0.434153 & 0.640585 & 0.297214 & 0.615535 & 0.622881 \\
\hline Intangible fixed assets (2014) & 0.424452 & 0.648449 & 0.282821 & 0.622622 & 0.632633 \\
\hline Intangible fixed assets (2013) & 0.409847 & 0.659733 & 0.265663 & 0.631335 & 0.642780 \\
\hline
\end{tabular}

Correlation of the indices of market value and intangible assets of UK enterprises for 2013-2017

\begin{tabular}{|l|c|c|c|c|c|}
\hline \multicolumn{1}{|c|}{ The United Kingdom } & $\begin{array}{c}\text { Market } \\
\text { capitalization } \\
(2017)\end{array}$ & $\begin{array}{c}\text { Market } \\
\text { capitalization } \\
(2016)\end{array}$ & $\begin{array}{c}\text { Market } \\
\text { capitalization } \\
(2015)\end{array}$ & $\begin{array}{c}\text { Market } \\
\text { capitalization } \\
(2014)\end{array}$ & $\begin{array}{c}\text { Market } \\
\text { capitalization } \\
(2013)\end{array}$ \\
\hline Intangible fixed assets (2017) & 0.494701 & 0.490851 & 0.491621 & 0.480456 & 0.442718 \\
\hline Intangible fixed assets (2016) & 0.484174 & 0.484933 & 0.487971 & 0.476199 & 0.440438 \\
\hline Intangible fixed assets (2015) & 0.458699 & 0.461741 & 0.458699 & 0.454515 & 0.420828 \\
\hline Intangible fixed assets (2014) & 0.452039 & 0.457368 & 0.453561 & 0.458510 & 0.428410 \\
\hline Intangible fixed assets (2013) & 0.405393 & 0.408100 & 0.404232 & 0.408487 & 0.429746 \\
\hline
\end{tabular}




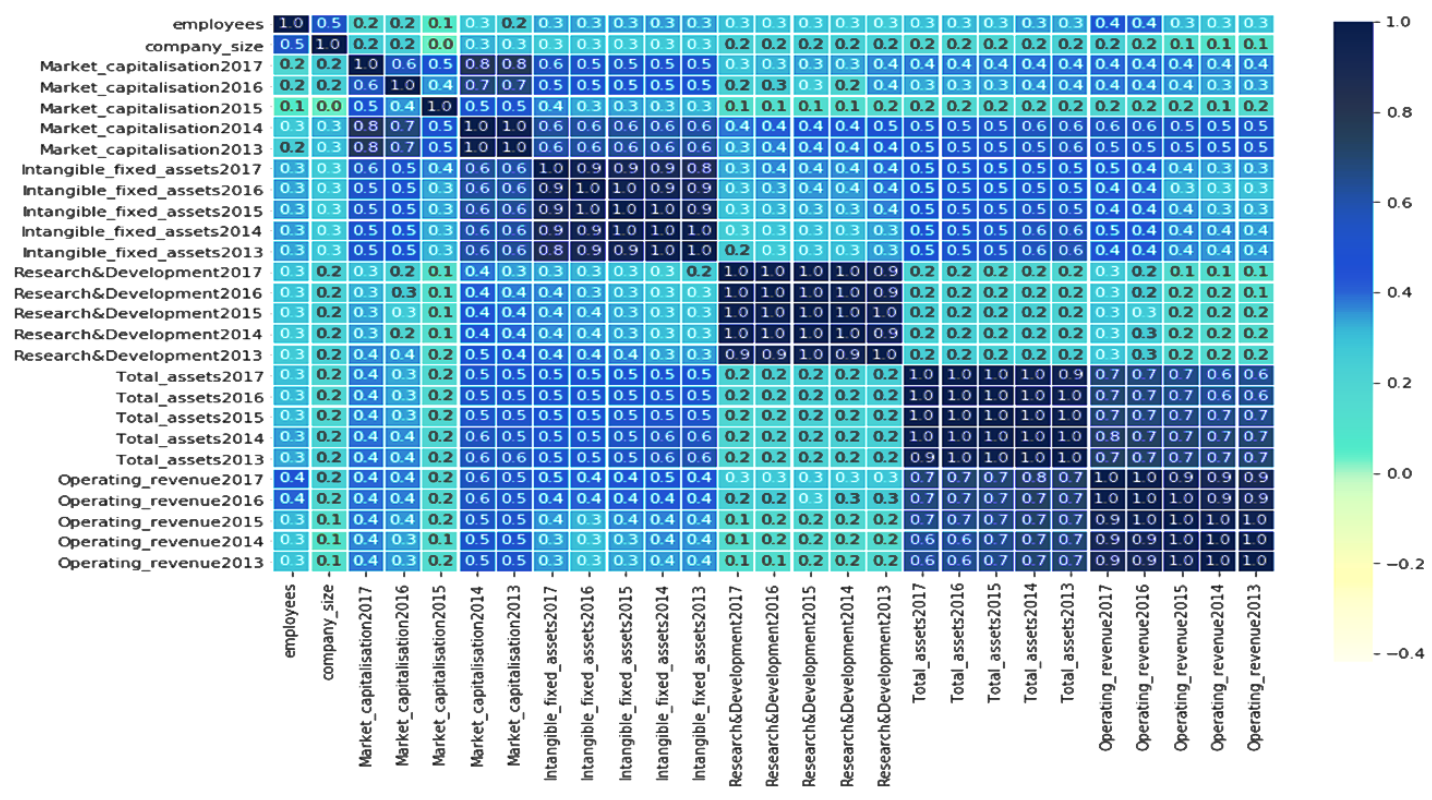

Fig. 1. General correlation matrix of reporting indicators of companies of Germany, France and the United Kingdom, of the "Top 500 EU"

ket capitalization, Intangible fixed assets, Research and Development, Total assets, Operating revenue.

Particular attention was paid to the correlation of intangible assets with other indicators. The analysis found that the highest correlation of indicators exists between Total assets, since the former ones are the part of the latter ones. Sufficient connection strength (0.6) is present in terms of Intangible fixed assets and Market capitalization. The lowest connection strength is between Research and Development and Total assets (0.2) and Research and Development and Operating revenue ( 0.2$)$, but it should be noted that, despite this, a moderate level of correlation between these costs is associated with intangible assets $(0.3-0.4)$. This can be explained by the fact that one of the areas related to incoming of intangible assets to the enterprise is the cost for research and development.

Since, under Hypothesis 1, it is necessary to establish the interdependence between the indicators of intangible assets and the market value of companies in certain countries (Germany, France and the United Kingdom), Fig. 2 provides a generalized thermogram for the correlation of the indicators of market value and intangible assets. The conducted studies show that there is a correlation between intangible assets and the market value of companies in certain countries (UK, Germany and France).

Moreover, the highest correlation of these indicators is present in the reporting forms of German enterprises (0.60.7 ), moderate and sufficient correlation of these indicators is traced in the reporting forms of enterprises in France $(0.3-$ 0.7 ) and sufficient connection strength is present in the reporting forms of UK enterprises (0.5-0.7) (Fig. 2). This confirms the hypothesis 1 .

Now we are testing hypothesis 2 . The density of distribution of indicators and long confidence interval of bootstrap in Fig. 3 indicate the lack of fullness of the indicators and the divergence of indicators of Market capitalization, Intangible fixed assets. Thus, for further research it is advisable to group the data by size of enterprises.

Therefore, to refute or confirm Hypothesis 2, the companies were grouped by size based on the number of employees and capitalization of intangible assets, depending on the size of the enterprises. The visualization of indicators is more evident when grouped into five groups, because the range of employees according to the reporting indicators ranges from 0 to 600000 people. Thus, the first group includes the range from 0 to 1000 people, the second group - from 1000 to 5000 people, the third one - from 5000 to 10000 people, the fourth one - from 1000 to 50000 people, the fifth one - more than 50000 people.
In Figs. 4 and 5 enterprises are grouped by size and availability of intangible assets and market value of enterprises in reporting forms of such countries as Germany, France and the United Kingdom for the period of 2013-2017. The visualization of the data in these figures shows that the maximum representation of intangible assets in reporting forms, as well as the increase in their weight share in total assets of enterprises is observed in small enterprises (number of employees up to 1000 people), large (number of employees from 10000 to 50000 people), and very large (employing more than 50000 people). In addition, Fig. 5 certifies that with the simultaneous decrease or increase in the intangible assets indicators, there is an almost simultaneous decrease or increase in the market value of the companies (so, for the first group - the amount of intangible assets in 2017 compared to 2013 increased almost 1.7 times, and the market value in 1.9 times; for the second group - the amount of intangible assets decreased by 0.6 times during this period, and the market value decreased by 0.7 times accordingly; the third group saw an increase in intangible assets by 1.1 times and the market value by 1.7 times; in the fourth group - the amount of intangible assets increased 1.5 times, and the market value almost 2 times; for the fifth group - the amount of intangible assets increased 1.3 times and the market value 1.3 times). The following tendency is observed at the enterprises with the number of employees from 1000 persons to 5000 persons (the second group), as well as the

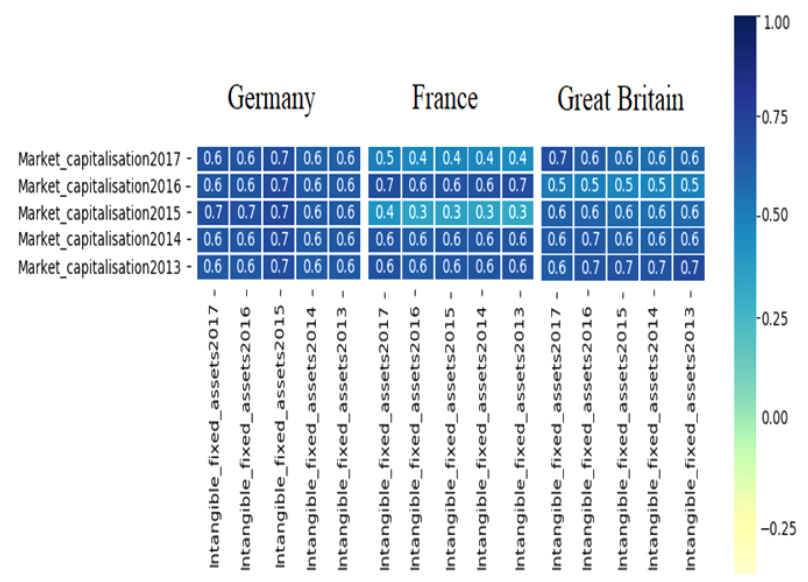

Fig. 2. Generalized thermogram of correlation of indicators of market value and intangible assets 


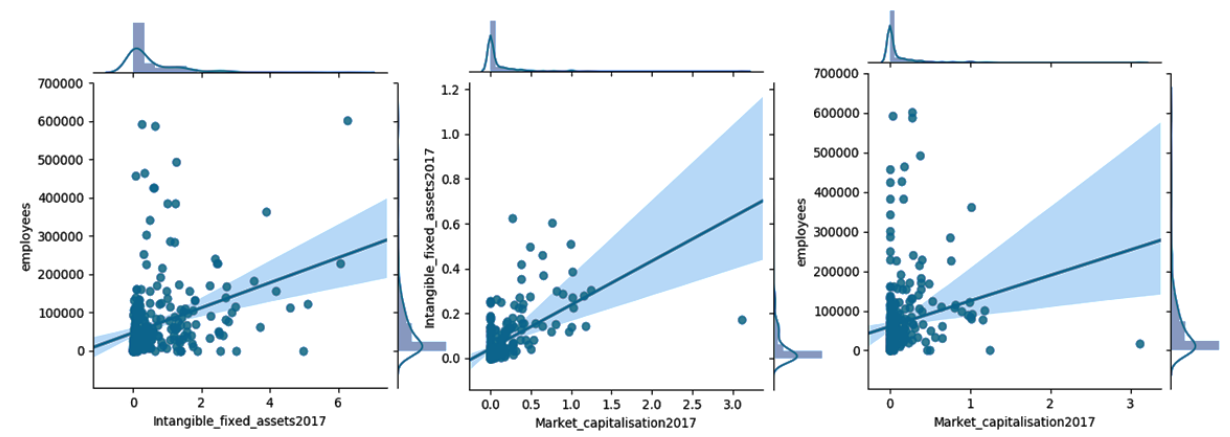

Fig. 3. Scatter chart for three countries (Germany, France and the United Kingdom) for 2013-2017

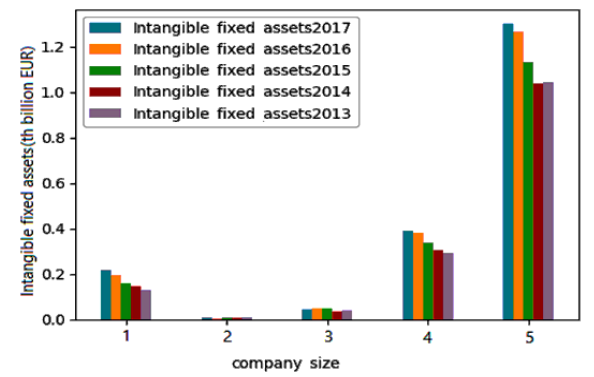

Fig. 4. Interconnection between enterprises' size and intangible assets indicators

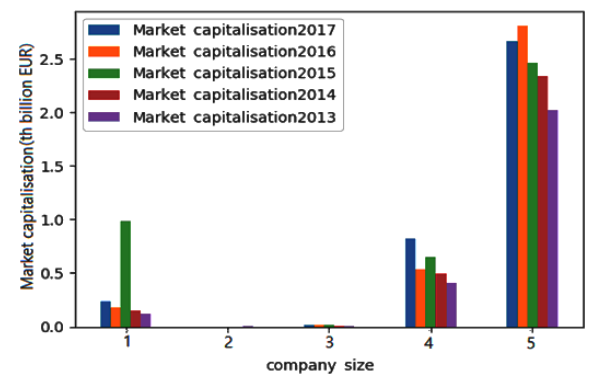

Fig. 5. Interconnection between of enterprises' size and enterprises' market value

enterprises with the number of employees from 5000 persons to 10000 persons (the third group): with a small weight of intangible assets, the market value of enterprises is also insignificant (Figs. 4, 5), even there is a decrease in the market value of enterprises for the period of 2013-2017.

Finally, we are testing hypothesis 3 . Fig. 6 shows the relation between the indicators of intangible assets by economic sectors and the market value of enterprises in individual countries (UK, Germany and France) (hypothesis 3).

The list of industries of three countries was grouped on the basis of NACE Code Index and Search [13]. Based on the fact that in "Top $500 \mathrm{EU}$ " not all industries were given indicators of intangible assets, so only 14 industries (the number of subspecies of economic activities: B (06, 08, 09), C (10, 12, 14, 19, $20,21,22,23,24,25,26,27,28,29,30,33)$, D (35), F (41, 42), $\mathrm{G}(45,46,47), \mathrm{H}(49,50,51,52,53), \mathrm{I}(56), \mathrm{J}(58,60,61,62)$, $\mathrm{K}(64,66), \mathrm{M}(69,70,71,72,73,74)$, N (79, 80, 82), O (84), $\mathrm{R}(92), \mathrm{S}(94,95,96))$ were grouped with relevant sub-sectors, for which the full composition of indicators of intangible assets over 5 years (2013-2017) was introduced (Fig. 6).

Visualization of indicators of intangible assets of three countries (Fig. 6) gives grounds to claim that the largest numbers of indicators of intangible assets are present in the following industries: $2-\mathrm{C}-$ MANUFACTURING, $8-\mathrm{J}-\mathrm{IN}$ FORMATION AND COMMUNICATION, $9-\mathrm{K}-$ FINANCIAL AND INSURANCE ACTIVITIES, $10-\mathrm{M}-$ PROFESSIONAL, SCIENTIFIC AND TECHNICAL AC-

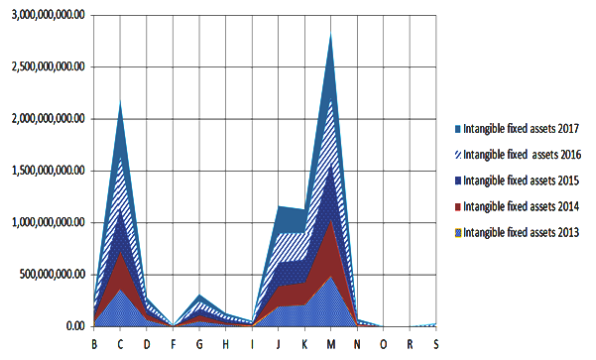

Fig. 6. Generalized interdependence of indicators of intangible assets and economic sectors (thousand $€$ )

TIVITIES, which is confirmed by the large number of enterprises belonging to these industries $(2,8)$, as well as by the types of activities of enterprises in these industries $(8-\mathrm{J}-\mathrm{IN}$ FORMATION AND COMMUNICATION: 58 Publishing activities; 59 Motion picture, video and television program production, sound recording and music publishing activities; 60 Programming and broadcasting activities; 61 Telecommunications; 62 Computer programming, consultancy and related activities; 9 - K - FINANCIAL AND INSURANCE ACTIVITIES: 64 Financial service activities, except insurance and pension funding; 66 Activities auxiliary to financial services and insurance activities; $10-\mathrm{M}$ - PROFESSIONAL, SCIENTIFIC AND TECHNICAL ACTIVITIES: 69 Legal and accounting activities; 70 Activities of head offices; management consultancy activities; 71 Architectural and engineering activities; technical testing and analysis; 72 Scientific research and development; 73 Advertising and market research; 74 Other professional, scientific and technical activities).

If we follow the dynamics of changes, the following maximum changes have taken place in the economic sectors in the period from 2013 to 2017 (Table 4): by industry C - MANUFACTURING - intangible assets increased by 1.49 times; by industry J - INFORMATION AND COMMUNICATION intangible assets increased by 1.34 times by industry K - FINANCIAL AND INSURANCE ACTIVITIES - intangible assets increased by 1.07 times; by industry M - PROFESSIONAL, SCIENTIFIC AND TECHNICAL ACTIVITIES - the increase occurred by 1.3 times.

Table 5 summarizes the indicators of total intangible assets by four above mentioned industries and market values for the period of 2013 and 2017 by three countries (Germany, France and the United Kingdom).

Thus, according to industry C - MANUFACTURING the value of intangible assets increased by 1.49 times and the amount of market value increased by 1.42 times; by industry J - INFORMATION AND COMMUNICATION - the value of intangible assets increased by 1.34 times and the market value increased by 1.22 times; by industry $\mathrm{K}$ - FINANCIAL AND INSURANCE ACTIVITIES - the value of intangible assets increased by 1.07 times and the market value increased by 1.56 times; by industry M - PROFESSIONAL, SCIENTIFIC AND TECHNICAL ACTIVITIES - the increase in 
Total intangible assets by all sectors of economic activity for the period of 2013-2017 for three countries (German, French and UK companies)

\begin{tabular}{|c|c|c|c|c|c|}
\hline NACE_LIT & $\begin{array}{c}\text { Intangible fixed assets } \\
2013\end{array}$ & $\begin{array}{c}\text { Intangible fixed assets } \\
2014\end{array}$ & $\begin{array}{c}\text { Intangible fixed assets } \\
2015\end{array}$ & $\begin{array}{c}\text { Intangible fixed assets } \\
2016\end{array}$ & $\begin{array}{c}\text { Intangible fixed assets } \\
2017\end{array}$ \\
\hline B & 1418981.00 & 49661528.00 & 56079682.00 & 54201242.00 & 70498712.00 \\
\hline C & 365964986.00 & 365196867.00 & 419037687.00 & 492126271.00 & 546399689.00 \\
\hline D & 69336920.00 & 53446742.00 & 56772836.00 & 55429619.00 & 50054833.00 \\
\hline F & 4090269.00 & 3476122.00 & 3398853.00 & 3530186.00 & 4497998.00 \\
\hline G & 56129056.00 & 57407887.00 & 66117545.00 & 66643309.00 & 69034612.00 \\
\hline H & 22085130.00 & 22384564.00 & 33958910.00 & 26497946.00 & 27262439.00 \\
\hline I & 10720517.00 & 11377817.00 & 12138030.00 & 12204082.00 & 12089277.00 \\
\hline J & 198169574.00 & 194084648.00 & 227962133.00 & 279393896.00 & 265683909.00 \\
\hline K & 214244018.00 & 213607292.00 & 221951347.00 & 252854973.00 & 229132050.00 \\
\hline M & 492757270.00 & 539700912.00 & 559387594.00 & 622038956.00 & 639201920.00 \\
\hline N & 12778051.00 & 12307931.00 & 12758592.00 & 12312082.00 & 26790041.00 \\
\hline O & 1084107.00 & 1073442.00 & 1057004.00 & 1087215.00 & 885686.00 \\
\hline R & 1025400.00 & 1253702.00 & 1436358.00 & 1383426.00 & 1180016.00 \\
\hline S & 3983032.00 & 3589776.00 & 8555000.00 & 9014000.00 & 8147000.00 \\
\hline
\end{tabular}

Table 5

Indicators of total intangible assets and market value by selected sectors of economic activity for 2013 and 2017 for three countries (German, French and UK companies)

\begin{tabular}{|c|c|c|c|c|c|c|}
\hline $\begin{array}{c}\text { NACE } \\
\text { LIT }\end{array}$ & $\begin{array}{c}\text { Intangible fixed } \\
\text { assets } 2013\end{array}$ & $\begin{array}{c}\text { Market } \\
\text { capitalization } \\
2013\end{array}$ & $\begin{array}{c}\text { Intangible fixed assets } \\
2017\end{array}$ & $\begin{array}{c}\text { Market } \\
\text { capitalization } \\
2017\end{array}$ & $\begin{array}{c}\text { Intangible fixed } \\
\text { assets }\end{array}$ & $\begin{array}{c}\text { Market } \\
\text { capitalization }\end{array}$ \\
\hline C & 365964986.00 & $8.18 \mathrm{E}+08$ & 546399689.00 & $1.16 \mathrm{E}+09$ & 1.49 & 1.42 \\
\hline J & 198169574.00 & $2.92 \mathrm{E}+08$ & 265683909.00 & $3.55 \mathrm{E}+08$ & 1.34 & 1.22 \\
\hline K & 214244018.00 & $1.9 \mathrm{E}+08$ & 229132050.00 & $2.96 \mathrm{E}+08$ & 1.07 & 1.56 \\
\hline M & 492757270.00 & $5.65 \mathrm{E}+08$ & 639201920.00 & $1.14 \mathrm{E}+09$ & 1.30 & 2.02 \\
\hline
\end{tabular}

intangible assets value by 1.3 times took place and the market value increased by 2.02 times. These indicators confirm the substantive content of hypothesis 3 .

Conclusion. This article provides an intellectual analysis of the impact of intangible assets on the market value of European enterprises, taking into account the specific types of countries (Germany, France and the United Kingdom), their size and the economic activity in which they operate. The study uses the correlation-regression analysis, in particular, based on the use of Python programming libraries (Pandas (for numeric tables and time series), Numpy (for mathematical calculations), Matplotlib and Seaborn (for data visualization)) tests the following hypotheses: Hypothesis 1 - there is the correlation between the indicators of intangible assets and the market value of companies in selected European countries (UK, Germany and France); Hypothesis 2 - there is the correlation between the intangible assets in terms of size of companies and the market value of enterprises in individual countries (UK, Germany and France); Hypothesis 3 - there is the correlation between the indicators of intangible assets by economic sectors and the market value of enterprises in individual countries (UK, Germany and France).

Overall conclusions are as follows. The correlation between intangible assets and the market value of companies in the analyzed European countries has been identified, but the strength of this connection is different. For German companies, the strongest connection is $0.6-0.7$, for French companies it is moderate and sufficient $0.3-0.7$, and for British companies it is sufficient ( $0.5-0.7)$, which confirms the hypothesis 1 . The evidence was also found to support hypothesis 2 that the size of an enterprise also affects the connection between intangible assets and the market value of enterprises. For five selected enterprise groups by their size, with simultaneous decrease or increase in intangible assets, there is an almost simultaneous decrease or increase in their market value. Hypothesis 3 was partially confirmed, in particular, that the intangible asset was not sufficiently substantiated only for industries $\mathrm{C}, \mathrm{J}, \mathrm{K}, \mathrm{M}$ and N, classified according to the NACE Code Index.

\section{References.}

1. Nitsenko, V., Mukoviz, V., \& Sharapa, O. (2017). Accounting of transaction expenses of economic entities. Scientific Bulletin of Polissia, 4(12), P. 2, 71-78. https://doi.org/10.25140/24109576-2017-2-4(12)-71-78.

2. Nitsenko, V., Chukurna, O., Mardani, A., Streimikis, J., Gerasymchuk, N., Golubkova, I., \& Levinska, T. (2019). Pricing in the Concept of Cognitive Marketing in the Context of Globalization: Theoretical, Methodological and Applied Aspects. Montenegrin Journal of Economics, 15(4), 131-147. https://doi.org/10.17512/pjms.2019.19.1.09.

3. Basso, L.F.C., Saliba de Oliveira, J.A., Kimura, H., \& Braune, E. S. (2015). The impact of intangibles on value creation: Comparative analysis of the $\mathrm{Gu}$ and Lev methodology for the United States software and hardware sector. Investigaciones Europeas de Dirección y Economía de la Empresa, 21, 7383. https://doi.org/10.1016/j.iedee.2014.09.001. 
4. Jaara, O. O., \& Elkotayni, Kh.A. R. (2016). The Impact of Intangible Assets Internally Developed on the Market Value of Companies "A Field Study in the Pharmaceutical Companies in Jordan". Accounting and Finance Research, 5(2), 154-163. https://doi.org/10.5430/afr.v5n2p154.

5. Nuryaman, N. (2015). The Influence of Intellectual Capital on The Firm's Value with The Financial Performance as Intervening Variable. Procedia - Social and Behavioral Sciences, 211, 292-298. https://doi.org/10.1016/j.sbspro.2015.11.037.

6. Sardo, F., \& Serrasqueiro, Z. (2017). A European empirical study of the relationship between firms' intellectual capital, financial performance and market value. Journal of Intellectual Capital, 18(4), 771-788. https://doi.org/10.1108/JIC-10-2016-0105.

7. Castro, W. B., \& Benetti, C. (2017). The impact of intangible assets on the market value of companies that compose the Brazilian stock exchange index. Impact of Intangible Assets on Companies' Market Values, 11, 1-13.

8. Glova, J., \& Mrazkova, S. (2018). Impact of Intangibles on firm value: an empirical evidence from European public companies. Ekonomicke časopis, 66(7), 665-680.

9. Ocak, M., \& Findik, D. (2019). The impact of intangible assets and sub-components of intangible assets on sustainable growth and firm value: evidence from Turkish listed firms. Sustainability, 11(5359), 1-23. https://doi.org/10.3390/su11195359. 10. Vasconcelos, T., Forte, D., \& Basso, L. F. C. (2019). The impact of intangibles of German, English and Portuguese companies from 1999 to 2016. Revista de Administração Mackenzie, 20(4), 1-38. https://doi.org/10.1590/1678-6971/eRAMF190164. 11. Forte, W., Matonti, G., \& Nicolo, G. (2019). The impact of intellectual capital on firms financial performance and market value: Empirical evidence from Italian listed firms. African Journal of Business Management, 13(5), 147-159. https://doi. org/10.5897/AJBM2018.8725.

12. Mačerinskienè, I., \& Survilaitè, S. (2019). Company's intellectual capital impact on market value of Baltic countries listed enterprises. Oeconomia Copernicana, 10(2), 309-339. https://doi.org/10.24136/oc.2019.016.

13. NACE Code Index and Search (2014). Retrieved from https:// statbank.cso.ie/px/u/NACECoder/NACEItems/searchnace. asp.

\section{Аналіз впливу нематеріальних активів на ринкову вартість компаній}

\section{В. В. Свдокимов ${ }^{1}$, Т. П. Остапчук ${ }^{1}$, С. Ф. Легенчук ${ }^{2}$, Д. О. Грицишен ${ }^{1}$, Г. В. Мариук ${ }^{1}$}

1 - Державний університет «Житомирська політехніка», м. Житомир, Україна, e-mail: ostapchuk-a@ukr.net

2 - Національне агентство із забезпечення якості вищої освіти, м. Київ, Україна

Мета. Визначення впливу нематеріальних активів на ринкову вартість європейських компаній (Німеччини, Франції та Великобританії) за допомогою інтелектуального аналізу даних.

Методика. Кореляційно-регресійний аналіз, включаючи бібліотеки програмування Python (Pandas, Numpy, Matplotlib, Seaborn), був використаний для пошуку зв'язку між ринковою вартістю й нематеріальними активами, доступними підприємствам, що надало можливість провести аналіз і візуалізацію результатів за допомогою різних методів. Для аналізу впливу виду галузі на взаємозв'язок між ринковою вартістю й нематеріальними активами використовувалася їх класифікація згідно з індексом коду NACE.

Результати. Кореляція між нематеріальними активами та ринковою вартістю компаній в аналізованих європейських країнах виявлена, але сила цього зв'язку різна (німецькі компанії $(0,6-0,7)$, французькі компанії $(0,3-0,7)$, британські компанії $(0,5-0,7))$. Розмір підприємства впливає на зв'язок між нематеріальними активами та рин- ковою вартістю підприємств. Автори роблять висновок, що співвідношення між показниками нематеріальних активів за галузями економіки та ринковою вартістю підприємств існує лише для деяких галузей економіки (C, J, K, М та N), класифікованих згідно з індексом NACE Code.

Наукова новизна. У дослідженні обгрунтована залежність ринкової вартості від інвестицій у нематеріальні активи європейських компаній (Німеччини, Франції та Великобританії), що дозволяє коригувати їх інвестиційну політику в залежності від галузі економічної діяльності, до якої відноситься компанія, та від іiї розміру.

Практична значимість. Визначення можливості впливу вартості нематеріальних активів на ринкову вартість компаній.

Ключові слова: нематеріальні активи, ринкова вартість, ринкова капіталізація, інтелектуальний аналіз даних, кореляція, регресія

\section{Анализ влияния нематериальных активов на рыночную стоимость компаний}

\section{В. В. Евдокимов ${ }^{1}$, Т. П. Остапчук ${ }^{1}$, С. Ф. Легенчук ${ }^{2}$, Д. А. Грицишен ${ }^{1}$, Г. В. Марчук ${ }^{1}$}

1 - Государственный университет «Житомирская политехника», г. Житомир, Украина, e-mail: ostapchuk-a@ukr.net 2 - Национальное агентство по обеспечению качества высшего образования, г. Киев, Украина

Цель. Определение влияния нематериальных активов на рыночную стоимость европейских компаний (Германия, Франция и Великобритания) с использованием интеллектуального анализа данных.

Методика. Корреляционно-регрессионный анализ, включая библиотеки программирования Python (Pandas, Numpy, Matplotlib и Seaborn), использовался для нахождения связи между рыночной стоимостью и нематериальными активами, доступными для предприятий, что позволило проводить анализ и визуализацию результатов с помощью различных методов. Для анализа влияния вида отрасли на взаимосвязь между рыночной стоимостью и нематериальными активами использовалась их классификация в соответствии с индексом кода NACE.

Результаты. Была выявлена корреляция между нематериальными активами и рыночной стоимостью компаний в анализируемых европейских странах, но сила этой связи различна (немецкие компании $(0,6-0,7)$, французские компании $(0,3-0,7)$, британские компании $(0,5-0,7))$. Размер предприятия влияет на связь между нематериальными активами и рыночной стоимостью предприятий. Авторы приходят к выводу, что корреляция между показателями нематериальных активов по отраслям экономики и рыночной стоимостью предприятий существует только для некоторых отраслей экономики (C, J, K, М и N), классифицированных в соответствии с Индексом кода NACE.

Научная новизна. В исследовании обоснована зависимость рыночной стоимости от инвестиций в нематериальные активы европейских компаний (Германии, Франции и Великобритании), что позволяет корректировать их инвестиционную политику в зависимости от отрасли экономической деятельности, к которой относится компания, и от ее размера.

Практическая значимость. Определение возможности влияния стоимости нематериальных активов на рыночную стоимость компаний.

Ключевые слова: нематериальные активы, рыночная стоимость, рыночная капитализация, интеллектуальный анализ данных, коррелящия, регрессия

Recommended for publication by V.S. Nitsenko, Doctor of Economic Sciences. The manuscript was submitted 14.10.19. 